\title{
Pricing Bodies: A Feminist New Materialist Approach to the Relations Between the Economic and Socio-Cultural
}

Contribution to Adkins, Lisa and Lehtonen, Turo-Kimmo (Eds) (2018) 'Price', Special Issue of Distinktion: Journal of Social Theory, 19: 2.

\section{Rebecca Coleman}

Sociology Department, Goldsmiths, University of London, London, SE14 6NW, UK. rebecca.coleman@gold.ac.uk

\section{Abstract}

Arguments that the economic and socio-cultural should be understood as relational and intertwined, and that price involves a reciprocal relationship between the economic and socio-cultural, are increasingly prevalent in the social sciences. I develop these notions of relationality and reciprocation through a feminist new materialist perspective, which emphasises the entanglement of and intra-action between what might usually be seen as independent and autonomous entities. To do this, I focus on a range of recent body-image initiatives, led by government, corporate and non-profit organisations, which aim to improve girls' and young women's levels of confidence and self-esteem. I explore how feminist theory tends to see such initiatives in terms of the expansion of the economic sphere into the sociocultural, which involves a tainting or contamination of embodiment and feeling. Rather than dispute these arguments, I take seriously theories and practices from cultural economy that see the economic and socio-cultural as co-constitutive. I augment these ideas with a feminist new materialist approach and argue that the economic and socio-cultural are in intra-active relations: they do not precede or exist apart from each other. In doing so, I consider how body-image initiatives can be understood as phenomena produced through these entangled intra-active relations, 
and offer an understanding of pricing as a simultaneously socio-cultural and economic process, where value and values become. I also raise questions regarding how, ethically and politically, boundary making and unmaking can be conceived, and how despite being in entangled relations, asymmetries between economic and sociocultural relations may be approached.

\section{Keywords}

body-image; ethics; entanglement; feminist new materialisms; phenomena; price; pricing

\section{Pricing Bodies:}

\section{A Feminist New Materialist Approach to the Relations Between the Economic and Socio-Cultural}

Arguments that the economic and socio-cultural should be understood not as separate spheres but as relational and/or intertwined are increasingly prevalent in the social sciences (e.g. Callon 1998, 2007, MacKenzie, Muniesa and Siu 2007, Bennett, McFall and Pryke 2008, Adkins and Lury 2012, Deville 2015) ${ }^{1}$. This paper aims to contribute to such arguments by drawing on some of the theories of price, which see a reciprocal relationship between the economic and socio-cultural (Zelizer 1985), and propose that quantity and quality, value and values, capital and bodies are coconstitutive (e.g. Muniesa 2007, Caliskan 2007, Adkins and Lehtonen 2018). I take up and develop these notions of reciprocation and co-constitution through a feminist new materialist perspective, which emphasises the entanglement and transformation of and intra-action between ${ }^{2}$ what might usually be seen as independent and 
autonomous entities, and which raise issues regarding how, ethically and politically, boundary making and unmaking can be conceived and approached (e.g. Barad 2007, Coole and Frost 2010, Coleman 2009). My aim is to both draw on and develop the theories of price and cultural economy ${ }^{3}$ discussed here through a feminist new materialist perspective.

Exactly how such relations and entanglements function and play out are empirical problems; this paper focuses on a range of recent body-image initiatives for girls and young women as a productive case study to examine them further. Such initiatives have proliferated since the early 2000 s - for instance in the UK Labour government's Body Image Summit (2000) and the Conservative and Liberal Democrat government's Body Confidence campaign (2010-2015) as well as more widely in what Sarah Banet-Weiser (2015) calls Girl Empowerment Organisations (GEOs); the 'variously corporate, non-profit and state-funded' organisations in the USA that aim to empower girls through improving levels of confidence, self-esteem, education and skills and that often have an international development focus (2015: 182, see also Koffman and Gill 2013, Koffman et al 2015). I suggest that such initiatives have tended to be seen in feminist theory in terms of the politically dubious expansion of the economic sphere into the socio-cultural, where feelings such as self-confidence and self-esteem become subject to calculation and commodification (e.g. BanetWeiser 2015, Koffman and Gill 2013, Koffman et al 2015, McRobbie 2009). Such theories therefore try to disentangle the economic and socio-cultural, so that feelings and girls' and young women's bodies remain outside of such calculations.

This paper does not dispute these arguments so much as to take seriously theories of cultural economy that see the economic and socio-cultural as co-constitutive, and from the feminist new materialisms that see the economic and socio-cultural as entangled. I propose that body-image initiatives be conceived as phenomena 
produced through processes whereby the symbolic and material, quantities and qualities, capital and bodies, measure and value, and calculation and feeling become entangled. Both 'phenomena' and 'entanglement' are concepts drawn from the work of feminist new materialist Karen Barad (2007), which account for how the world is, ontologically, relational, processual and transformative. Further, these concepts attend to the ethics and politics of how particular materialities (in this case, bodies in the body-image initiatives) are made, or cut, through specific practices. I expand on these ideas below. Throughout the paper is a concern with how feeling - both the specific bodily feelings of confidence and self-esteem and the affective appeal of doing good more generally - are involved in price and pricing. In these senses, the paper seeks to contribute both to feminist accounts of body-image initiatives and related processes and to contemporary debates about the ethical or moral economy (Arvidsson 2009, Shamir 2008) and price and pricing. A central question it explores is what a feminist new materialist approach might offer to understandings of bodyimage initiatives, price and pricing and the relations between the economic and socio-cultural.

\section{Body-image initiatives: The move of the economic into the socio-cultural}

In June 2000, the UK Labour government held a Body Image Summit to examine links between a rise in young women reporting eating disorders, self-harm, widespread dieting and a more general dissatisfaction with their bodies, and images in the media and fashion industries. The Body Image Summit responded explicitly to a British Medical Association report, 'Eating Disorders, Body Image and the Media' (2000) which argued that:

The media provide particular examples of role expectations and images of beauty which may influence young people's perceptions of acceptable body image. The images of slim models in the media are a stark contrast to the 
body size and shape of most children and young women who are becoming increasingly heavier (BMA 2000).

In particular, the report notes the role of media images in creating low self-esteem that can assist in the development of eating disorders:

In recent years the socially represented ideal body has become increasingly thin, and much thinner than the average objective body shape of the population, putting pressure on women to view their bodies as fatter and heavier. Research has shown that girls with low self esteem at age 11-12 were at significantly greater risk of developing severe signs of eating disorders and other psychological problems at age 15-17 (BMA 2000).

Announcing the Summit in April 2000, and taking on the language used by the BMA, Tessa Jowell, the Minister for Women at the time who organised and chaired the Summit, commented that, 'For many, poor body image can lead to low levels of self esteem, for some it is dangerous, leading to eating disorders and other forms of selfabuse'. She went on to note that, 'I am concerned that girls may not be fulfilling their potential because of their lack of confidence about themselves' (Jowell, quoted in BBC 2000).

One of the central ways that 'potential' is understood and mobilised in this initiative is in terms of economic potential; that is in terms of what a bolstering or improvement of girls' and women's confidence, self-esteem and general feelings about their bodies could contribute to their ability to succeed at school and in work, and thus to the economy more widely. Jowell was careful not to imply that the summit would result in regulations of the media and fashion industries that would restrict their economic potential, remarking on 'the important contribution these industries make to the 
economy' (see Coleman 2009, 4). Rather, the aim was to unlock the potential of girls and women, by encouraging a more diverse range of body types and shapes in media representations.

It would be incorrect to state that girls' and women's potential was only expressed in terms of economic potential in this summit. One of the summit's most high-profile attendees was psychoanalyst Susie Orbach, who gave a keynote address. Following the UK general election in 2001, won again by Labour, Orbach urged the new Minister for Women, Patricia Hewett, to follow up on the spirit and recommendations of the 2000 summit, writing that she could have 'a quiet but deeply important contribution to the lived experience of women in Britain today' (Orbach 2001). This contribution is framed as the most significant achievement that Hewitt might make; however, Orbach also notes Hewitt's dual position as both Minister for Women and Minister for Trade and Industry:

She can and should encourage the fashion industry to see the economic logic of designing and making clothes in the sizes that women actually come in, even perhaps giving bursaries to design students leaving college who are willing to reshape and diversify the currently limited aesthetic (Orbach 2001).

Addressing body-image issues might also have further macro economic effects, for example by 'sav[ing] the hidden costs, paid by the health service, by doing preventative medicine rather than cleaning up the mess' (Orbach 2001).

Despite Orbach's encouragement, government initiatives on body-image, selfesteem and confidence seemed to wane for the rest of the Labour government, but were picked up again with the emergence of a coalition government of the Conservative and Liberal Democrat parties following the general election in 2010. 
The establishment of a Body Confidence Campaign in 2010 by Liberal Democrat MPs Lynne Featherstone and Jo Swinson was followed by regular meetings and activities held until $2015^{4}$, placing these issues back on the governmental agenda.

Discussing what the campaign had achieved from 2010-2012, Swinson highlights its aim to 'bring[...] together partners in the media, fashion and fitness industries, as well as those who spend their days trying to heal the damage caused by low self-esteem and distorted views of eating and exercise' (Swinson 2012). In these more recent initiatives, body-image, self-esteem and confidence are again framed in terms of economic potential: Swinson argues that '[w]omen are at the heart of the country's growth strategy and we need to do everything possible to harness their talents and skills'.

It is important to note that Swinson's comments come in the wake of financial crisis of 2008 , at a time when the UK was in recession, and when economic growth dominated government discussions (as it still does today). Indeed, in the 2013 annual report on the Body Confidence Campaign, Swinson frames body-image, selfesteem and confidence in economic terms:

As a Minister in the Department for Business Innovation and Skills, I am also very aware of the critical importance of releasing women's full contribution to economic growth. In order to do this we need to address the remaining structural barriers - by modernizing workplaces and ensuring access to flexible, accessible, affordable childcare. However we also need to tackle the cultural barriers, which include raising girls' aspirations and vision of all the ways in which they can be valued and fulfilled (GEO 2013,3). 
Notable here is Swinson's grouping of body-image issues as cultural, in contrast to the structural or economic issues concerning workplaces and childcare. Here then, the cultural is framed as the realm of bodily feelings (confidence, self-esteem, aspirations) as distinct from the economic, which involves structural or market-based concerns - but it is also seen as a necessary issue to tackle to achieve economic growth. The socio-cultural and economic are here, then, both distinct and inextricable from each other.

Indeed, commenting on the 'enormous waste of women's time, talent and emotional wellbeing, sacrificed to the pursuit of looking like someone else or a digitally modified image in the media', Swinson repeats this idea: 'As a government that seeks to maximise the talents of everyone, and in particular to support women's increased contribution to economic growth, we are very concerned about the opportunity cost associated with low body confidence' (GEO 2013, 7). Such comments are further reiterated in the 2015 Annual Report on the campaign, where 'poor body image' is described as 'not just a problem for individuals. It is an equalities issue, limiting the opportunities and rewards on offer to some sections of society, and punishing people unfairly if they step out of proscribed roles'.

\section{Feminist critiques: Re-asserting the boundaries between the economic and socio-cultural}

As these examples make clear, in these various initiatives bodily feelings such as self-esteem and confidence are located as cultural issues that become framed in economic terms. A number of prominent feminist critics have drawn attention to how neoliberalism expands the scope of the market into spheres that have traditionally been seen as social, cultural and/or personal, with specific implications for the construction of and demand placed on female subjectivity (e.g. McRobbie 2009, Conor, Gill and Taylor 2015, Adkins 2002, Adkins and Dever 2015, 2106). Banet- 
Weiser, for example, discusses the rise of GEOs in the USA, understanding them as operating in a neoliberal 'market for empowerment, where empowerment itself becomes a commodity. GEOs provide market logic for commodified empowerment, and target an imagined feminine subject who is both in crisis and a powerful consumer' $(2015,182)$. She notes that GEOs are part of a process of

marketisation in a context where markets have expanded beyond conventional economic formations to encompass emotional or personal markets, where such things as self-esteem and empowerment can be branded and sold (Banet-Weiser 2012, 2014). What these branding strategies accomplish, in part, is the transformation of emotions and social relations into products, around which industries can be built $(2015,183)$.

Often, such GEOs operate transnationally, encouraging those in the 'developed' world to value and invest in girls in the 'developing' world. 'The Girl Effect', an international programme developed by the Nike Foundation in partnership with the United Nations and the World Health Organisation in the mid 2000s is a good example of such an initiative, based on the premise that 'Girls are the most powerful force for change on the planet' and summarised as such:

We want to help create a 'new normal' for girls. A world in which girls are not held back from reaching their full potential: either by themselves, their families or their communities. A world in which girls can stay in school, get access to health services, get married and have children when they choose, realise their economic potential and their dreams: because they demand it and because others in their lives demand it, for them too (www.girleffect.org/about-us). 
The Girl Effect works across various mediated campaigns, including on social media, roadshows and in the promotion of merchandising. Analysing The Girl Effect, Ofra Koffman and Ros Gill (2013) argue, among other things, that in focusing on girls, the project 'depict[s...] girls in developing countries as entrepreneurial "subjects in waiting", in which extreme poverty is regarded as having the potential to stimulate entrepreneurial capacities' (2013: 85). Such a move, they suggest, involves a 'selective uptake of feminism and [...] yok[ing] discourses of girl power, individualism, entrepreneurial subjectivity and consumerism together with rhetorics of "revolution" that - perhaps paradoxically - renders invisible the inequalities, uneven power relations and structural features of neo-liberal capitalism that produce the very global injustices that the Girl Effect purports to challenge' (2013: 86).

In her analysis of the Girl Effect, Michelle Murphy (2012) explores similar themes, and introduces the concept of 'human capital', coined in the 1960s by Theodore Schultz and associated with Chicago School economist Gary Becker. Human capital is a distinctly neoliberal understanding of,

the knowledge, skills, values, personality, and health embodied in people that make them economically productive. [...] the term 'human capital' designates the embodied capacities of a person that can produce future economic benefits for that person, her employer, and even her national economy (Murphy 2012) . $^{5}$

Drawing on this conception of human capital, Murphy makes a coupling between 'the affective bonds between Western liberal feminists and financial logics. This abundance of investment in The Girl marks the hypervaluation of the anticipatory "potential" of The Girl as an effect of financialisation and simultaneously draws into juxtaposition a set of unspoken devaluations'; that is, as she goes on to argue, The 
Girl's 'rates of return are so high precisely because her value begins so low. The girl is an undervalued stock for global finance and for future global economic recover precisely because she is constituted as the "poorest of the poor"' (Murphy 2012).

It is clear to see the connections between the initiatives that Banet-Weiser, Koffman and Gill and Murphy discuss and those from the British government focused on body-image. Of significance in the feminist analyses l've outlined briefly here are what Murphy, in the title of her paper, refers to as the 'mergers of feminism and finance' (and here it should be noted that by feminism she is referring to the (neo)liberal feminism of an activity like The Girl Effect rather than the critical feminism that characterises her argument). Banet-Weiser and Murphy, as well as many other feminist theorists, are critical of such merging - for producing a specifically economic version of contemporary (young) femininity, for commodifying the emotional and personal, and for capitalising on the devaluation of girlhood globally. Hence, while perhaps implicit in their arguments, there is an inference that finance and feminism/girlhood/embodiment/feeling should not be merged, or that feminism/girlhood/embodiment/feeling would be better if they were not merged with the economic market. What it is possible to suggest, then, is that at stake in feminist analyses such as these is an attempt to re-assert the boundaries between the economic and the socio-cultural, embodiment and feeling. That is, there is an implicit understanding that in any version of feminism, (girls' and young women's) embodiment and feeling, the economic should not be present. Or, put another way, in the extension of the economic market beyond its traditional sphere, the merging of embodiment and feeling with finance involves a tainting or contamination of embodiment and feeling, which should be avoided or reversed.

\section{Price: The reciprocal relations between economic value and socio-cultural} values 
I am sympathetic to the critique of the exploitation of girlhood, femininity, embodiment and affective capacity for financial ends and am not arguing that such a process does not take place, and does not place girls and bodies understood as feminine in a position where their potentiality can be marketised and commodified. Indeed, I return to such issues below. However, at the same time - and as this feminist theory engages with - recent work on cultural economy argues that the economic and socio-cultural are not separate spheres and therefore cannot be held apart. Rather, they are performative (e.g. Callon 1998) and constitutive (Callon 2007) of each other. For example, Michel Callon (2007) argues that 'markets can be seen as contributing actively to the manufacture of the social' (2007: 146). By this, he refers to a process whereby markets function inevitably to create 'matters of concern' around which a group forms - a social. In this sense, a market creates a social. Furthermore, these groups themselves feed back into markets, re-defining the market that was initially of concern, or creating a new version. Of importance to my argument here is that, while distinct, the socio-cultural and economic are coconstitutive. It is not only that they do not have clear borders; it is also that they 'contribute actively' to the creation of each other. As Tony Bennett, Liz McFall and Mike Pryke (2008) put it, culture, economy and the social 'are not pre-formed objects: they are given shape and meaning by a host of socio-cultural-technical practices' (2008: 1), and in being shaped in these ways, are themselves heterodox and diverse.

Such arguments are taken up explicitly in terms of the neoliberal process of marketization discussed above. On the one hand, processes of marketization and financialisation extend economic logics into social and cultural institutions and activities. On the other hand, corporations and businesses show how they operate not only to make profit, but also for a socially recognised good (e.g. Arvidsson 2009, Banet-Weiser 2012). In Ronen Shamir's (2008) terms, a central tenant of these neoliberal processes is a simultaneous - if uneven - moralisation of the economy 
and economisation of morality, so that ' $[\mathrm{b}] \mathrm{oth}$ state and non-state institutions in fields such as health, education, security and welfare are transfigured to act as if embedded in a competitive environment where the laws of economics reign (2008: 1) and 'socio-moral questions - traditionally the concerns of civic groups, liberaldemocratic parliaments, trade unions and political parties - become "the business of market actors"' (2008: 3).

Theories of price are productive in comprehending the specificities of the configurations of the relations between the socio-cultural and the economic. More especially, they can be productive in examining further how the relations between bodily feeling and the economic are potentially more complex, multiple and mutually constitutive than a uni-directional move of the economic into the sphere of the sociocultural might suggest. In her work on price, economic sociologist Viviana Zelizer (1985) poses the following questions: 'what is the general nature of the relationship between economic and noneconomic factors in social life, between price and value? How does the market deal with $[\ldots]$ aspects of society that are regulated by sentiment and value, not price?' $(1985,13)^{6}$. The broader context for asking these questions is what Zelizer describes, before the performative turn instigated by Callon and others, as:

Three underlying assumptions [that] shape most observations about the nature of the relationship between the market and nonmarketable personal values. First, price and value are entirely dichotomous categories; second, economic concerns are constantly and inevitably enlarging; and third, the power of price to transform (usually corrupt) values is unquestioned, while the reciprocal transformation of price by value is seldom conceptualised (1985, 18-19). 
For Zelizer then, sociology is dominated by arguments about the expansion of the economic into the realm of the socio-cultural, which, in its ideal state, is imagined to be distinct from 'economic concerns'. Hence, the move of the economic into the noneconomic is primarily seen in negative terms - that is, finance, money and price not only transform but also corrupt socio-cultural values.

While there has been a range of work that complicates and troubles such assumptions - as I have noted - such ideas, remain important today, as my discussions so far have served to illustrate. Hence, despite being proposed over thirty years ago, Zelizer's aim to consider the relationship between the economic and socio-cultural in terms of a counter-movement remains pertinent. How do values, sentiment and feelings themselves shape economic pricing? Indeed, she argues that '[t]he power of the market has been over-estimated' $(1985,21)$, and that,

The 'commercialisation effect' has its precise counterpart - a reciprocal 'sacralisation' process by which values shape price, investing it with social, religious, or sentimental meaning. How is the market shaped by these cultural and social factors? $(1985,21)$.

Significantly for my concern with how it is the feelings of girls and young women in particular that are at stake in body-image initiatives, the focus of Zelizer's argument here is on the child. She tracks the processes by which, in the USA from the nineteenth to twentieth centuries, socio-cultural understandings of the child shift from seeing the child as 'useful' to 'useless'. ${ }^{7}$ While middle- and upper-class children have always been capable of being exempted from the economic sphere ${ }^{8}$, from the nineteenth century there is also a shift from understanding working-class children in terms of labour and wages - and hence as 'useful' - and in the twentieth century across all classes, education and sentimentality become the primary lens through 
which the child is conceived. Broadly speaking then, Zelizer charts a historical process of 'sacralisation', whereby the child becomes understood as 'priceless'.

Analysing legal cases, news reporting and public opinion, Zelizer details how the sacralisation of the child not only creates new markets, and in so doing brings the 'priceless child' into economic calculation, but also transforms understandings of economics, markets and pricing themselves. Indeed, summarising her argument, she suggests:

A profound paradox was created. The twentieth-century family was defined as a sentimental institution, "the antithesis of a market economy's concept of human relations", as Carl Degler aptly puts it. Yet, even the family seemed to capitulate to the dominant cash nexus, as the value of its most precious member, the sacred child, was now routinely converted into its monetary equivalent. Had the child lost its economic value only to be become another commercial commodity? My findings strongly suggest that the sentimental value of children served as a bulwark against the market. [...] Priceless values were being priced, but the pricing process itself was transformed by its association to value. In child death awards, insurance policies for children, and adoptive payments for a child, money is to a certain extent deprived of its economic worth. Instead, such monetary payments acquire powerful symbolic meanings $(1985,210-211)$.

Zelizer's argument here is that the economic and socio-cultural are in reciprocal relations. As the child becomes 'priceless' it enters into new economic markets and modes of calculating its financial value. At the same time, the economic processes by which the priceless child is priced are shaped by sentiment and feeling, or the socio-cultural. Examples such as this demonstrate both the changing and mutually 
constitutive relations between the economic and socio-cultural. In this sense, they demonstrate how quantities, money and calculation - 'the economic' - not only shape, impact on and determine but are also themselves subject to qualities, values and feelings - the socio-cultural.

\section{Pricing: Entangling the socio-cultural and economic}

While Zelizer understands the socio-cultural and economic as capable of transforming each other, it is important to recognise that she maintains that there is a mutually oppositional distinction between them; that is, Zelizer opposes price (as economic) to values (as socio-cultural). This distinction indicates that the economic and socio-cultural are in reciprocal relations but ultimately remain in separate domains. The distinction between them is 'external' ${ }^{9}$ in that the economic and sociocultural interact but remain discrete. For instance, in addition to the quotations referred to above, in her initial definition of price, Zelizer states:

In this context, the term price, which has a variety of different technical and lay meanings, represents economic worth, as distinct from noneconomic determinants of value $(1985,13)$.

For Zelizer, then, economic and non-economic versions of value reside in the economic and socio-cultural spheres. Price may be shaped by socio-cultural values, but it remains economic. In the arguments from cultural economy discussed above, however, the socio-cultural and economic are in more entwined relations. These entwined relations have implications for more recent understandings of price, pricing and valuation. For example, Fabian Muniesa (2007) develops a pragmatist approach to price, which 'diverge[s] from any attempt at defining objectivity and subjectivity as a binary opposition', and any 'straightforward distinction between prices and values' (2007, 378). Furthermore, in his explanation of price in cotton trading, Koray Caliskan 
(2007) notes that while it is an 'important first step' to draw attention to how prices are social and cultural as well as economic, such an argument is not, in itself, sufficient, for it 'does not necessarily help us locate the rich nature of prices, the multiple forms that they take and the manifold locations where they are produced even in a single or regional market' $(2007,241)$. Instead, he argues, what is required is an understanding of 'the material processes where prices are made and the rich world of prices that define the processes of market making' $(2007,241)$.

While not responding to Caliskan's call in its entirety, I am also interested in materiality in so far as I am considering what a feminist new materialist approach might indicate for price and pricing. Feminist new materialisms understands matter as an ongoing process of materialisation through the constitutive relations between bodies, technologies and environments. As Barad puts it: 'matter [i]s a dynamic and shifting entanglement of relations, rather than a property of things' (2007: 224). Importantly for an understanding of price and pricing, Barad's conception of matter/materialisation is that:

the world isn't naturally broken up into social and scientific realms that get made separately. There isn't one set of material practices that makes science, and another distinct set that makes social relations; one kind of matter on the inside, and another on the outside. The social and the scientific are co-constituted. They are made together - but neither is just made up. Rather, they are ongoing, open-ended, entangled material practices (2007, 168).

For Barad here, materialisations involve the co-constitution of the social and scientific through 'internal' relations. What might be taken up from this for a conception of price and pricing is that the socio-cultural and economic are 'made together'. What might 
be considered objective and quantitative on the one hand, and subjective and qualitative on the other, are in fact 'entangled practices'. In this sense, pricing becomes a process through which value and values become, both materially and symbolically. Indeed, rather than locating price and value in distinct realms focus should instead be placed on pricing as a simultaneously socio-cultural and economic process. Such a shift from price to pricing is both to see the economic and sociocultural as necessarily entangled (rather than separate) and to attend to pricing as a process through which such an entanglement takes place.

The move to the term 'entanglement' here is to consider the ways in which the economic does not only frame, move into or shape the socio-cultural or bodily feelings, but becomes intertwined with them. Across the humanities and social sciences the take up and use of the term 'entanglement' is becoming increasingly popular, and is increasingly employed in 'catch-all' and non-specific ways. The way in which I mobilise it in this paper draws from Barad's (2007) work on the coconstitution of matter and meaning. Here, entanglement refers not to 'just any old kind of connection, interweaving, or enmeshment in a complicated system' (2007, $160)$. Instead, '[t]o be entangled is not simply to be intertwined with another, as in the joining of separate entities, but to lack an independent, self-contained existence' (2007, ix). In other words, entanglement refers to how entities that might seem bounded or autonomous are in constitutive, transformative and open-ended relations. As such, entanglement indicates an ontological position whereby the world is becoming through relations. One dimension of understanding the body-image initiatives through such a conception of entanglement then, is that the socio-cultural or bodily feeling and the economic are not separate entities or spheres, but rather are in mutually constitutive, 'internal', relations. 
It is in this way that I want to understand pricing - as an 'ongoing, open-ended, entangled material practice[...]'. Further, Barad's argument is that such practices create what she terms 'phenomena': 'the ontological inseparability/entanglement of intra-acting agencies' $(2007,139)$. The term phenomena seeks to designate how 'basic units of reality' $(2007,139)$ are relationally produced; that is, entities do not exist before or outside of relations but are constituted through them. This sense of how entities are produced relationally is captured in the term 'intra-action', which Barad coins in distinction to the more familiar 'interaction'. Whereas 'interaction assumes that there are separate individual agencies that precede their interaction, the notion of intra-action recognises that distinct agencies do not precede, but rather emerge through, their intra-action' (2007: 33).

If pricing is conceived as an entangled practice that produces phenomena, how might the theoretical approaches and the body-image initiatives of interest in this paper be understood? What, in other words, might a feminist new materialist approach have to offer an understanding of the body-image initiatives at stake here? My aim in posing and addressing these questions is to attempt to demonstrate the particular inflection that a feminist new materialist approach might bring to understanding body-image initiatives. However, this does not involve a repudiation of the other approaches concerning cultural economy and price discussed above. In other words, rather than reject them, I draw on these approaches and refract them through a feminist new materialist approach.

\section{The sacralisation of body-image}

Zelizer's argument would suggest that, while self-esteem and bodily confidence are brought into the economic market, it is worth considering whether a reciprocal relationship between feeling and economics is also taking place. In this sense, whilst the feminist analyses on body-image initiatives l've discussed above are certainly not 
misplaced or mistaken, they may not capture the ongoing and unfinished reciprocation between the economic and socio-cultural. Moreover, a move from Zelizer's to Barad's argument would highlight not only the reciprocal relations between the economic and socio-cultural but also their entanglement. Such a move may seem relatively minor, but, I suggest, it involves some significant differences.

Taking up Zelizer's argument in terms of body-image initiatives, we might inquire not only into how the economic 'frames' the socio-cultural, but also how the socio-cultural shapes the economic. Picking up on the point made by Orbach regarding the most significant aspect of the Body Image summit in 2000 - that is, 'a quiet but deeply important contribution to the lived experience of women in Britain today' (Orbach 2001) - shows how socio-cultural concerns as well as economic ones are involved in the aims and outcomes of the initiative. Similarly, Swinson's comments regarding the necessity of 'tackl[ing] the cultural barriers' that restrict women from reaching their economic potential, gesture towards how the economic is not separate to but rather entwined with the socio-cultural. In these senses, then, the socio-cultural and economic are not mutually oppositional categories, nor is it the economic that necessarily impedes on the socio-cultural. However, while they may have a reciprocal relationship, the independence of the economic and socio-cultural spheres is maintained. That is, as discussed above, for Zelizer, a distinction is maintained between the economic (defined in terms of value) and the socio-cultural (defined in terms of values). The concept of entanglement, though, indicates the 'lack [of] an independent, self-contained existence'. In this case, while for various reasons as I discuss below, distinctions and boundaries may be made between them, the economic and socio-cultural are in intra-active relations. This is to suggest that distinctions between the economic and socio-cultural may be made, but these distinctions do not precede or exist apart from each other. 
Such an approach can be explicated through a more specific example. For instance, responding to Zelizer's argument regarding sacralisation, it becomes possible to ask whether, in developed Western societies today, there is a sacralisation process of body-image, self-esteem and confidence similar to that which occurred with the child in the nineteenth and twentieth centuries. That is, as the child generally has been sacralised, are girls and young women in particular sentimentalised? And, if this is the case, are body-image, self-esteem and confidence - feelings that are seen as most intensely experienced by girls and young women - becoming sentimentalised so that, as feelings and values, they are involved in the transformation of markets, measures, and prices?

In the emphasis on them as central to the production of both her own and her nation's economic value, the bodily potential of girls and young women become invested with 'social, moral and sacred values' (Zelizer 1985, 212). For example, Murphy details how 'The Girl' is represented in campaigns such as The Girl Effect as 'visually optimistic, hopeful, and animated'. She is 'imbued with the feminist promise of agency, translated into the promise of value-added capital'. In this sense, as well as the economic expanding into the realm of the socio-cultural, the socio-cultural can be seen as involved in the transformation of the economic. Drawing on Zelizer's and cultural economy approaches, then, the 'merging' of 'the affective bonds between Western liberal feminists and financial logics' that Murphy points to is a multidirectional or reciprocal relationship so that a particular version of liberal feminist empowerment has not only been incorporated into existing financial markets, but has also created new markets - GEOs for instance - and transformed these markets in terms of what they must take into account - girls and young women, liberal feminism, bodily feelings. The economic value of the market has therefore not only impacted upon the symbolic and material values of girls and young women, but the sociocultural values concerned with girls and young women have also impacted upon 
economic value. Quantitative value has to some extent been shaped by qualitative values. As Turo-Kimmo Lehtonen (2014) puts it in an analysis of private life insurance, 'economic value and other values overflow into each other and [...] without this overflowing life insurance would not exist at all. In other words, it is the dynamic movement between different spheres of valuation that renders life insurance, on the whole, its value as a technology' (2014: 329).

Developing these arguments, a feminist new materialist approach, which emphasises the entangled and transformative processes via which phenomena are produced, might see the emergence of GEOs as a phenomenon; as an entity that has been produced through the entangled relations between the economic and socio-cultural. Here, rather than the economic and socio-cultural interacting - existing as separate spheres that impact upon and shape each other - they intra-act. If intra-action 'signifies the mutual constitution of entangled agencies' (Barad 2007: 33, emphasis in original), the economic and socio-cultural can be understood as agencies (rather than spheres) that are entangled and mutually constitutive. That is, the economic and socio-cultural are distinct (in the sense that they are particular kinds of agency), but this distinction is an 'internal' rather than 'external' relationality.

Consider a further example, which demonstrates from a slightly different angle how a phenomenon is produced through entangled economic and socio-cultural relations. To return to Zelizer's point regarding how quantity is 'culturally defined', the Body Confidence Campaign 2015 Annual Report notes that poor body-image 'reduces women's economic, political and social power. Poor body-image is associated with lower confidence, lower aspirations and lower social participation. If you aim for less, less is generally what you get' $(2015,7)$. Cited as evidence of this assertion is the Women's Business Council report, ‘Maximising women's contribution to future economic growth' (2013), which states that: 
By equalling the labour force participation rates of men and women, the UK could further increase GDP per capita growth by 0.5 percentage points per year, with potential gains of $10 \%$ of GDP by 2030 . We need to address this mismatch to unlock women's contribution for the UK to optimise its economic potential (http://womensbusinesscouncil.dcms.gov.uk/introduction/).

Here, the quantity quoted - an increase of $10 \%$ of GDP by 2030 - can be understood to function in terms of what Georg Simmel, quoted by Zelizer $(1985,163)$, describes as the 'fantastic possibilities that transcend the definiteness of numbers'. Such a large and vague quantity of money 'attain[s] a special distinctive quality' (Simmel quoted in Zelizer 1985, 163). From Zelizer's and cultural economy positions, quantity and quality are here in reciprocal relations so that quality has the capacity to define quantity. From a feminist new materialist perspective, it is not only that quality and quantity can shape and define each other, but also that they become entangled, producing a phenomenon (the Body Image initiative) that 'transcends' the economic and socio-cultural spheres.

A similar process occurs in the one of the films in Girl Effect campaign ${ }^{10}$. This film proposes that 'the future of humanity' can be altered by investing in a (poor twelve year old) girl (from a developing country). The Girl Effect moves in a smooth and unidirectional manner: girl $>$ school $>$ cows $>\$>$ business $>$ clean water $>$ social change $>$ stronger economy $>$ better world. In this sequence, which progresses from the micro (one child) to macro (better world), the vagueness of the quantities (how much do 'we' invest? what constitutes a 'stronger economy'?) can be understood to 'transcend the definiteness of numbers', so that quantity and quality again become entangled ${ }^{11}$. 
Importantly, to take up Zelizer's argument, the entanglement of quantity and quality occurs in part, through sentiment. That is, girls and young women here become sacred beings - or in Murphy's terms, a 'subject figure' - that appeal to the audience through affect and emotion. The campaign is intended to have an affective appeal on 'us', the audience, who ideally should be moved to invest in The Girl Effect. Furthermore, affect, feeling and sentiment are involved in the aims of the campaign to 'do good'. Such an aim may be understood in terms of Shamir's notion of the moralisation of the economy, whereby 'commercial enterprises increasingly perform tasks that were once considered to reside within the civic domain of moral entrepreneurship and the political domain of the caring welfare state, dispensing social goods other than profits to constituencies other than their shareholders' (2008, 2). In this sense, the Girl Effect and the body-image initiatives emanating from other GEOs are instances of corporations doing good through taking on moral and social tasks. At the same time as this moralisation of the economy, Shamir points to a concurrent process of the economisation of morality; 'a process which is compatible with the general neo-liberal drive to ground social relations in the economic rationality of markets' $(2008,3)$. The framing of social and cultural issues as economic issues in the UK government's body-image initiatives might be understood in this way.

The body-image initiatives might also be understood in terms of what Adam Arvidsson (2009) calls the ethical economy, 'in which value derives from social organisation'. Arvidsson's conceptualisation of the ethical economy is an attempt to consider how values or ethics are increasingly part of the economy, and are increasingly organised around philia, or 'positive affective bonds' $(2009,20)$. Arvidsson's focus is primarily on how such good feelings are produced through immaterial labour, and on how they are central to the ways in which brands function. This focus is helpful for understanding body-image initiatives such as The Girl Effect, which sought not only to affectively appeal to audiences of the video, but to involve 
them, Nike Foundation partners and girls within the campaign (Kylander 2011). Indeed, the Girl Effect website is an open source platform, so that materials can be downloaded by any interested parties. Maria Eitel, founder of the Nike Foundation and previously the Vice President of Corporate Responsibility at Nike Inc. explained that the decision to design the website in this way was because 'We wanted something that people could get behind and make their own [...] the world needed a rallying point, and the Girl Effect is a movement that belongs to everyone' (cited in Kylander 2011, 2). What is noteworthy in Arvidsson's approach for my argument concerning feminist new materialisms, is that 'doing good' is not something that has been incorporated into the economic realm, which is thus supposed as uninterested in morals, ethics and feeling. Rather, 'doing good' is an inextricable part of how the economy functions; socio-cultural values have become entangled with economic value. Indeed, I would suggest that initiatives concerned with 'doing good', such as those regarding body-image, might be seen to entangle the socio-cultural and economic, values and value, in such a way as to produce a new phenomena; that is, not (only) to merge, blur or flow across the boundaries between the socio-cultural and economic, but to create new 'units of reality'.

\section{Conclusion: Entanglement, cutting and ethics}

In considering what, if anything, is distinctive in the feminist new materialist approach I am proposing here compared to the other theoretical positions I have discussed, a number of issues are raised. At the same time as I am drawing on the approaches offered by Zelizer and theorists working on cultural economy, I am also seeking to highlight a difference. This difference is perhaps clearest in terms of Zelizer's argument, which, while it highlights the reciprocity between the economic and sociocultural, ultimately maintains a division between them, and places value (price, worth) and values in each, mutually exclusive, respective sphere. Price is an economic issue that may impact on - interact with - values, but is fundamentally 
separate to it. In contrast, the feminist new materialist notion of pricing that I am proposing sees value and values as entangled, that is 'to lack an independent, selfcontained existence' (2007, ix). The distinction between the feminist new materialist approach and the cultural economy approaches is perhaps more difficult to distinguish, given that both recognise the relationality and dynamism of the economic and socio-cultural. However, in understanding the production of phenomena, the feminist new materialist approach draws attention to entangled relationality. The feminist new materialist approach not only attends to the co-constitutive relations between the economic and socio-cultural but also their capacities to produce particular kinds of phenomena. In the case of the body-image initiatives discussed here, this is to consider them as particular kinds of units of reality that are created through the entanglement of relations. It is also to consider the particularities of the girls' and women's bodies created through them as themselves phenomena. It is thus to understand body-image initiatives as the intra-action between material practices of value and values, quantification and qualification, calculation and feeling.

It is critical to note that such an approach does not necessarily deny the existence of different kinds of practices, nor that some practices may collect together as economic issues or agencies, for example, and others as socio-cultural issues or agencies. In the entanglement of the economic and socio-cultural then, "'distinct" agencies are only distinct in a relational, not an absolute, sense, that is, agencies are only distinct in relation to their mutual entanglement; they don't exist as individual elements' (Barad 2007, 33). At this point, a further question is raised regarding the distribution or relative power of these agencies; after all, the feminist work discussed above does not deny that values, qualities and feelings are present in body-image initiatives, but rather argues that they are subjugated, transformed and, perhaps, corrupted by value, quantification and calculation. Indeed, while the feminist theories of GEOs are aware of, and indeed draw on, the cultural economy approaches discussed above, 
they nevertheless want to dis-entangle the economic and socio-cultural; to draw attention to the asymmetrical relations that the economic and socio-cultural are in. While I have suggested that socio-cultural values may themselves transform economic value - through processes of sacralisation and sentimentalisation, for example - this feminist work raises important questions regarding the politics and ethics of price and pricing. To what extent does the agency of economics come to dominate socio-cultural ones in the body-image initiatives discussed here? How, in these body-image initiatives, is pricing a series of processes and practices that are political and ethical, constituting not materially neutral bodies, but specific kinds of bodies, concerned with particular kinds of issues (increasing low levels of bodily confidence and self-esteem for instance), and realising 'potential' in ways that contribute to local, national and global economies?

Questions such as these can be addressed through a concern with an 'ethics of mattering' (Barad 2007, 36) - where ethics are integral or internal to the material phenomenon that is produced through entanglements. Importantly, such a conception of ethics requires that attention be paid to boundary making practices and the cuts through which these material phenomena are produced (Barad 2007, 160). Cuts, for Barad, are in part, what comes to produce a temporarily stable or coherent phenomena; they 'produce determinate boundaries and properties' (Barad 2007: 148). If phenomena are ongoing processes of materialisation, and if these processes of materialisation are relational entanglements, what relations become especially significant? What boundaries are brought together or made distinct in an entanglement? Through what cuts are phenomena created, and how might they be cut differently?

Responses to these questions depend on the 'vantage point' (Barad 2007, 158) from which they are considered; that is, ethics are themselves situated within or as part of 
the entanglement that they seek to understand, make sense of and take a position on. Ethics are 'embodied in the very worlding of the world' (Barad 2007, 160). For Barad, 'vantage points' are themselves partial and situated, as 'theorising and experimenting are not about intervening (from outside) but about intra-acting from within, and as part of, the phenomena produced' $(2007,56)$. While cuts enact boundaries, these cuts are also 'part of the phenomena they help to produce' (2007: 145). For social, cultural and feminist theorists interested in body-image initiatives, an ethical position might be to emphasise the dominance of economic relations as compared to the socio-cultural, and/or to argue for the boundaries between the economic and socio-cultural to be (re-)drawn, or cut, more strictly. What such an understanding implies is that while the economic is not a 'sphere' that moves into and 'colonises' the socio-cultural, the 'internal' relations between the economic and socio-cultural may still be asymmetrical and this asymmetry may still be criticised. Indeed, this is what I have suggested is at stake in the feminist theories that I have discussed above. However, taking up the notions of the reciprocal or entangled relations between the socio-cultural and economic that I have also discussed, an ethical position might also be to consider ethics as an empirical problem (see also Fraser 2009, Coleman 2008, 2009). In this sense, the vantage points from which to examine the ethics of body-image initiatives - and hence ethical responses or cuts may differ depending on whether they come from the position of girls and young women (and importantly, which girls and young women - in developed or developing countries, for example?), of politicians, journalists, psychoanalysts, medics, corporate organisations, brands and indeed academics. The simple, but consequential, suggestion is: Change the vantage point, change the cut, change the phenomena. 
While such an understanding of ethics is perhaps frustrating in that it does not lend itself to any easily identifiable or guiding principles, what it does enable is an attention to how, as Barad puts it,

ethics is not simply about the subsequent consequences of our ways of interacting with the world, as if effect followed cause in a linear chain of events. Ethics is about mattering, about taking account of the entangled materialisations of which we are a part, including new configurations, new subjectivities, new possibilities - even the smallest cuts matter $(2007,384)$.

My argument here is that if pricing is understood as the entanglement of the sociocultural and economic through which material phenomena are created, and if ethics is itself entangled within this process, it is necessary to pay attention to what and how distinct agencies or entities become entangled, and how they may be cut, and cut again differently. Indeed, I would suggest that taking seriously both the arguments concerning pricing as a reciprocal relation between the economic and socio-cultural and entanglement as a necessarily relational process, indicates that while attempts to dis-entangle the economic and socio-cultural are noble and understandable, they will, ultimately, be futile. That is, in the production of phenemona such as body-image initiatives, the economic and socio-cultural are not so much separate, existing prior to their relationality, as produced through their intraaction. Here, then, the socio-cultural and economic do not precede but rather are consequences of the production of the phenomena of body-image initiatives. Such an approach might change both the questions we ask of 'doing good' initiatives and how we might produce or cut them differently.

\section{Acknowledgements}


Thank you to Lisa Adkins and Turo-Kimmo Lehtonen for both their patience and incisive comments on previous drafts. Thanks also to Liz Moor and the anonymous reviewers for their constructive comments on earlier versions. While I have not been able to address them all, they have, I hope, helped me to clarify my argument.

\section{References}

All links accessed $31^{\text {st }}$ March 2016, unless otherwise indicated.

Adkins, L. 2002. Revisions: Gender and Sexuality in Late Modernity. Buckingham: Philadelphia: Open University Press.

Adkins, L. and Dever, M. Eds. 2014. Gender and Labour in New Times. Australian Feminist Studies Special Issue, 29: 79.

Adkins, L. and Dever, M. Eds. 2016. The Post-Fordist Sexual Contract: Working and Living in Contingency. Basingstoke: Palgrave Macmillan.

Adkins, L. and Lehtonen, T-K. Eds. 2018. 'Price', Special Issue of Distinktion: Journal of Social Theory, 19: 2.

Arvidsson, A. 2009. The ethical economy: Towards a post-capitalist theory of value. Class and Capital 33: 1: 13-29.

Banet-Weiser, S. 2015. 'Confidence you can carry!': Girls in crisis and the market for girls' empowerment organisations. Continuum 29: 2: 182-193. 
Barad, K. 2007. Meeting the Universe Halfway: Quantum Physics and the

Entanglement of Matter and Meaning. Durham and London: Duke University Press.

Bennett, T. McFall, L and Pryke, M. 2008. Editorial: Culture/economy/social. Journal of Cultural Economy. 1: 1: 1-7.

British Broadcasting Association. 2000. Government 'summit' over thin models. BBC News, $10^{\text {th }}$ April 2000: http://news.bbc.co.uk/1/hi/uk_politics/708186.stm

British Medical Association. 2000. BMA takes part in body image summit. Press Release, $21^{\text {st }}$ June 2000:

http://web.bma.org.uk/pressrel.nsf/wall/6F75AF7A34C7AEBF8025692100346D5A?O penDocument.

Callon, M. Ed. 1998. The Laws of the Market, Oxford: Blackwell.

Callon, M. 2007. What does it mean to say that economics is performative? in Mackenzie, D., Muniesa, F., Sui, L. Eds. 2007. Do Economists Make Markets? Princeton: Princeton University Press: 311-557.

Caliskan, K. 2007. Price as a market device: Cotton trading in Izmir mercantile exchange. Sociological Review 55, Issue Supplement s2: 242-260.

Coleman, R. 2008. A Method of Intuition: Becoming, Relationality, Ethics. History of the Human Sciences, 21(4): 104-123.

Coleman, R. 2009. The Becoming of Bodies: Girls, Images, Experience. Manchester: Manchester University Press. 
Conor, .B, Gill, R. and Taylor, S. 2015. Gender and creative labour. Sociological Review, 63, Issue Supplement S1: 1-22.

Coole, D. and Frost, S. 2010. Introducing the new materialisms. In Eds. New Materialisms: Ontology, Agency, and Politics. Durham and London: Duke University Press: $1-46$.

Day, S., Lury, C. and Wakeford, N. 2014. Number ecologies: Numbers and numbering practices. Distinktion: Journal of Social Theory 15: 2: 123-154.

Deville, J. 2015. Lived Economies of Default: Consumer Credit, Debt Collection and the Capture of Affect. London: Routledge.

Fraser, M. 2009. Experiencing Sociology. European Journal of Social Theory 12: 1: 63-81.

Government Equalities Office. 2013. Body confidence campaign, Progress report 2013:

https://www.gov.uk/government/uploads/system/uploads/attachment_data/file/20340 5/130501_body_confidence_progress_reportv03.pdf

Government Equalities Office. 2015. Body confidence campaign, Progress report 2015:

https://www.gov.uk/government/uploads/system/uploads/attachment_data/file/41718 6/Body_confidence_progress_report_2015.pdf 
Guyer, J. 2014. Percentages and perchance: Archaic forms in the twenty-first century. Distinktion: Journal of Social Theory 15: 2: 155-173.

Koffman, O. and Gill, R. 2013. The revolution will be led by a 12-year-old girl!: Girl power and global biopolitics. Feminist Review 105: 83-102.

Koffman, O., Orgad, S. and Gill, R. 2015. Girl power and 'selfie humanitarianism'. Continuum, 29: 2: 157-168.

Lehtonen, T.-K. 2014. Picturing how life insurance matters. Journal of Cultural Economy. 7: 3: 308-333.

Mackenzie, D., Muniesa, F., Sui, L. Eds. 2007. Do Economists Make Markets? Princeton: Princeton University Press.

McRobbie, A. 2009. The Aftermath of Feminism: Gender, Culture and Social Change. London: Sage.

Muniesa, F. 2007. Market technologies and the pragmatics of prices. Economy and Society 36: 3: 377-395.

Murphy, M. 2012. The Girl: Mergers of feminism and finance in neoliberal times. The Scholar \& Feminist Online 11.1-11.2, Fall 2012/Spring 2013:

http://sfonline.barnard.edu/gender-justice-and-neoliberal-transformations/the-girlmergers-of-feminism-and-finance-in-neoliberal-times/

Orbach, S. 2001. Give us back our bodies. The Observer. 21st June 2001: http://www.theguardian.com/politics/2001/jun/24/Whitehall.uk. 
Shamir, R. 2008. The age of responsibilisation: On market-embedded morality. Economy and Society 37: 1: 1-19.

Skeggs, B. 2015. Values beyond value? Is anything beyond the logic of capital? British Journal of Sociology 65: 1: 1-20.

Stark, D. 2009. The Sense of Dissonance: Accounts of Worth in Economic Life. Princeton and Oxford: Princeton University Press.

Swinson, J. 2012. It's been a year of success for the Body Confidence Campaign but where next? Huffington Post, $28^{\text {th }}$ December 2012:

http://www.huffingtonpost.co.uk/jo-swinson/where-next-for-the-body-confidencecampaign_b_2376661.html.

Women's Business Council. 2013. Maximising women's contribution to future economic growth:

https://www.gov.uk/government/uploads/system/uploads/attachment_data/file/20475 1/DCMS_WBC_Full_Report_v1.0.pdf

Zelizer, V. 1985. Pricing the Priceless Child: The Changing Social Value of Children. Princeton: Princeton University Press.

Zelizer, V. 2005. The Purchase of Intimacy. Princeton: Princeton University Press.

Zelizer, V. 2010. Economic Lives: How Culture Shapes the Economy. Princeton: Princeton University Press. 


\section{Notes}

${ }^{1}$ In this article, I use the term 'socio-cultural' rather than either 'the social' or 'the cultural'. While this terminology is in some ways problematic in drawing together the social and cultural, it is intended to draw attention to how, in the examples I discuss, boundaries are drawn and/or complicated between value and worth (economic) and values (social, cultural). ${ }^{2}$ Barad (2007) prefers the term 'intra-action' to interaction, noting that interaction assumes some kind of linkage or communication between two autonomous and independent entities, while intra-action draws attention to the ontological condition of the world as co-constitutive, relational entanglement; see e.g. Barad $(2007,33)$ and below.

${ }^{3}$ While recognising that this field is large and diverse and encompassing STS, cultural studies, economic sociology and political economy for example, for ease in this paper, I term this position 'cultural economy'.

${ }^{4}$ Featherstone and Swinson served as Parliamentary Secretaries for Women and Equalities between 2010-2015. As the Conservatives were the larger party in the coalition government, Conservative MPs occupied the Ministerial position: Theresa May (2010-2012), Maria Miller (2012-2014), Nicky Morgan (2014-2015).

${ }^{5}$ Throughout Murphy's argument runs a concern with speculation and futurity - hence, with human capital, 'embodiment becomes a kind of future-oriented value'.

${ }^{6}$ Note here that Zeliker refers to socio-cultural value in the singular, rather than in the plural as I do here. My terminology of socio-cultural values in counter-distinction to economic value comes from the problematic 'Parson's Pact' described by David Stark as marking the boundaries between economics and sociology: 'You, economists, study value; we, the sociologists, will study values. You will have claim on the economy; we will stake our claim on the social relations in which economies are embedded' $(2009,7)$. It is also this boundary making that I seek in this paper to in some way trouble.

${ }^{7}$ In other work, Zelizer has also examined the reciprocal relationships between the economic and intimate spheres (2005), and more widely how culture shapes the economy (2010).

${ }^{8}$ through the association between the upper classes and leisure and education for example

${ }^{9}$ Thanks to Turo-Kimmo Lehtonen for making this point sharper to me and suggesting this terminology. 
${ }^{10}$ See: 'The Girl Effect', https://www.youtube.com/watch?v=WlvmE4_KMNw

${ }^{11}$ Here, then there is a productive link to be made with how Sophie Day, Celia Lury and Nina Wakeford (2014) conceive of number as social, and in particular Jane Guyer's (2014) account of the significance of the vagueness of number. 